\title{
Switchgrass Response to Nitrogen Fertilizer Across Diverse Environments in the USA: a Regional Feedstock Partnership Report
}

\author{
C. O. Hong • V. N. Owens • D. Bransby • R. Farris • \\ J. Fike - E. Heaton - S. Kim • H. Mayton - R. Mitchell • \\ D. Viands \\ Published online: 3 June 2014 \\ (C) The Author(s) 2014. This article is published with open access at Springerlink.com
}

\begin{abstract}
The Regional Feedstock Partnership is a collaborative effort between the Sun Grant Initiative (through Land Grant Universities), the US Department of Energy, and the US Department of Agriculture. One segment of this partnership is the field-scale evaluation of switchgrass (Panicum virgatum L.) in diverse sites across the USA. Switchgrass was planted $\left(11.2 \mathrm{~kg}\right.$ PLS ha $\left.{ }^{-1}\right)$ in replicated
\end{abstract}

C. O. Hong

Department of Life Science and Environmental Biochemistry, Pusan

National University, Miryang 627-706, South Korea

V. N. Owens $(\bowtie) \cdot$ S. Kim

Plant Science Department, South Dakota State University,

Brookings, SD 57007, USA

e-mail: vance.owens@sdstate.edu

D. Bransby

Department of Agronomy and Soils, Auburn University, Auburn,

AL 36849, USA

R. Farris

Eastern Research Station, Oklahoma State University, Haskell,

OK 74436, USA

J. Fike

Department of Crop and Soil Environmental Sciences, Virginia Tech, Blacksburg, VA 24061, USA

E. Heaton

Department of Agronomy, Iowa State University, Ames, IA 50011, USA

H. Mayton $\cdot$ D. Viands

Plant Breeding and Genetics Department, Cornell University, Ithaca, NY 14850, USA

R. Mitchell

Grain, Forage and Bioenergy Research Unit, USDA-ARS, Lincoln, NE 68583, USA plots in New York, Oklahoma, South Dakota, and Virginia in 2008 and in Iowa in 2009. Adapted switchgrass cultivars were selected for each location and baseline soil samples collected before planting. Nitrogen fertilizer $(0$, 56 , and $112 \mathrm{~kg} \mathrm{~N} \mathrm{ha}^{-1}$ ) was applied each spring beginning the year after planting, and switchgrass was harvested once annually after senescence. Establishment, management, and harvest operations were completed using fieldscale equipment. Switchgrass production ranged from 2 to 11.5 $\mathrm{Mg} \mathrm{ha}{ }^{-1}$ across locations and years. Yields were lowest the first year after establishment. Switchgrass responded positively to $\mathrm{N}$ in 6 of 19 location/year combinations and there was one location/year combination (NY in Year 2) where a significant negative response was noted. Initial soil $\mathrm{N}$ levels were lowest in SD and VA (significant $\mathrm{N}$ response) and highest at the other three locations (no $\mathrm{N}$ response). Although $\mathrm{N}$ rate affected some measures of biomass quality ( $\mathrm{N}$ and hemicellulose), location and year had greater overall effects on all quality parameters evaluated. These results demonstrate the importance of local field-scale research and of proper $\mathrm{N}$ management in order to reduce unnecessary expense and potential environmental impacts of switchgrass grown for bioenergy.

Keywords Switchgrass $\cdot$ Biomass $\cdot \mathrm{N}$ fertility $\cdot$ Regional Feedstock Partnership

$\begin{array}{ll}\text { Abbreviations } \\ \text { N } & \text { Nitrogen } \\ \text { SD } & \text { South Dakota } \\ \text { NY } & \text { New York } \\ \text { IA } & \text { Iowa } \\ \text { OK } & \text { Oklahoma } \\ \text { VA } & \text { Virginia }\end{array}$


Year 1 The first year after establishment

Year 2 The second year after establishment

Year 3 The third year after establishment

\section{Introduction}

Switchgrass has been extensively studied for its value as a forage, conservation, and bioenergy crop [2, 20, 22, $25,27]$. It offers a number of distinct benefits to many annual row crops including broad adaptation, improved soil conservation and quality $[13,20]$, reduced greenhouse gas emissions [19], and carbon sequestration [6, $13,16,17,26]$. In particular, it has high yield potential on land marginal to row crop production [23]. In a previous work in South Dakota, USA, Mulkey et al. [23] found that switchgrass grown in marginal soil was well suited for sustainable biomass energy production.

Although switchgrass tolerates low soil fertility, optimizing biomass and maintaining quality stands require nitrogen $(\mathrm{N})$ fertilizer inputs and proper management. Switchgrass may respond positively to $\mathrm{N}$ fertilization, but its response varies with regional environment and soil fertility [8, 10-12, 14, 22, 23, 32]. Switchgrass biomass increased with increasing $\mathrm{N}$ rates up to $168 \mathrm{~kg} \mathrm{ha}^{-1}$ in low organic matter and low fertility soils in Texas, USA [22], and Vogel et al. [32] reported that each $\mathrm{Mg}$ of switchgrass biomass required 10 to $12 \mathrm{~kg} \mathrm{~N} \mathrm{ha}^{-1}$ in the Midwestern USA. However, Mulkey et al. [23] reported no benefit with $\mathrm{N}$ application rates above $56 \mathrm{~kg} \mathrm{ha}^{-1}$ on switchgrass-dominated Conservation Reserve Program (CRP) lands in South Dakota. In an analysis of 19 switchgrass research publications in the literature, Wullschleger et al. [34] noted that both upland and lowland switchgrass ecotypes responded to total $\mathrm{N}$ levels of approximately $100 \mathrm{~kg} \mathrm{~N} \mathrm{ha}^{-1}$; however, in some cases, the $0 \mathrm{~N}$ control produced as much biomass as switchgrass treated with $100 \mathrm{~kg} \mathrm{~N} \mathrm{ha}{ }^{-1}$. A major question regarding switchgrass management as a bioenergy crop is optimizing $\mathrm{N}$ application rate at the field scale since excessive $\mathrm{N}$ fertilization may result in adverse environmental and economic effects.

Direct comparisons of $\mathrm{N}$ fertilization in replicated switchgrass field trials across the USA are limited. This study is one segment of the Regional Feedstock Partnership, a program funded by the US Department of Energy and coordinated by the Sun Grant Initiative, which was designed to evaluate dedicated herbaceous energy crops and CRP land across environmental gradients in the USA. Specifically, the objective of this research was to assess switchgrass yield potential and quality under varying levels of $\mathrm{N}$ and grown in different environments using field-scale agricultural practices.

\section{Materials and Methods}

\section{Site Description}

This study was conducted at five locations across the USA including South Dakota (SD), New York (NY), Iowa (IA), Oklahoma (OK), and Virginia (VA). The SD location was near Bristol, SD (45 $\left.16^{\prime} 8.274^{\prime \prime} \mathrm{N} ; 97^{\circ} 50^{\prime} 8.9694^{\prime \prime} \mathrm{W}\right)$ on a Nutley-Sinai (silty clay, mixed, Chromic Hapluderts) with 2-20\% slope; the NY location was near Ithaca, NY $\left(42^{\circ}\right.$ $\left.27^{\prime} 44.5896^{\prime \prime} \mathrm{N} ; 76^{\circ} 27^{\prime} 38.1882^{\prime \prime} \mathrm{W}\right)$ on an Erie channery (fine-loamy, mixed, mesic Aeric Fragiaquepts) with 2$8 \%$ slope; the IA location was near Ames, IA ( $41^{\circ} 58^{\prime}$ $\left.59.001^{\prime \prime} \mathrm{N} ; 93^{\circ} 41^{\prime} 50.0346^{\prime \prime} \mathrm{W}\right)$ on a Clarion-Nicolette (fine-loamy, mixed, mesic Typic Hapludolls) with 0-9 \% slope; the OK location was near Muskogee, OK $\left(35^{\circ} 44^{\prime}\right.$ 32.9994" N; $\left.95^{\circ} 38^{\prime} 21.12^{\prime \prime} \mathrm{W}\right)$ on a Parsons-Carytown (fine, mixed, thermic Mollic Albaqualfs-Albic Natraqualfs) with 0-3\% slope; and the VA location was near Pittsylvania, VA $\left(36^{\circ} 55^{\prime} 56.2656^{\prime \prime} \mathrm{N} ; 79^{\circ} 11^{\prime}\right.$ 23.8842" W) on a Mayodan (fine sandy loam, mixed, thermic Typic Hapludults) with 2-15\% slope.

\section{Experimental Design and Field Management}

Information for each location (cultivar, planting date, total field size, and harvest date) are presented in Table 1. Seeding rate at each location was $11.2 \mathrm{~kg}$ pure live seed $\mathrm{ha}^{-1}$. Herbicides were applied as needed to control broadleaf and grassy weeds at each location. Since we did not have sufficient resources to plant all cultivars at all locations, one locally adapted switchgrass cultivar was selected for each site. The experimental design was a randomized complete block with four replications across the landscape. Individual plot size ranged from 0.4 to 0.8 ha to allow for use of conventional agricultural equipment. Stand establishment was determined using a frequency grid method [33] at each location the year of and year after seeding. The number of grid samples taken at each location was 12 (IA), 32 (NY), 10 (OK), 20 (SD), and 8 (VA). Three levels of $\mathrm{N}$ fertilizer $(0,56$, and $112 \mathrm{~kg} \mathrm{~N} \mathrm{ha}^{-1}$ ) were applied annually beginning the year after establishment at all locations. Nitrogen source was either urea or ammonium sulfate. Switchgrass was harvested once annually around a killing frost the year after establishment (year 1), the second year after establishment (year 2), the third year after establishment (year 3), and the fourth year after establishment (year 4) for SD, NY, OK, and VA. Since the IA location was planted in 2009 , only year 1 (2010), year 2 (2011), and year 3 (2012) data are included. In VA, switchgrass was harvested in January of the following year to allow adequate drying of biomass or when excessive autumn precipitation prevented the use of equipment on the field. 
Table 1 Location, cultivar, planting date, field size, and 2009-2012 harvest dates for switchgrass field trials at five locations across the USA

\begin{tabular}{|c|c|c|c|c|c|c|c|}
\hline \multirow[t]{2}{*}{ Location } & \multirow[t]{2}{*}{ Cultivar } & \multirow[t]{2}{*}{ Planting date } & \multirow[t]{2}{*}{ Field size (ha) } & \multicolumn{4}{|l|}{ Harvest date } \\
\hline & & & & 2009 & 2010 & 2011 & 2012 \\
\hline OK & Blackwell & 2 September 2008 & 7.3 & 13 November & 28 October & 16 December & 5 November \\
\hline NY & Cave-In-Rock & 29 May 2008 & 4.9 & 22 October & 2 November & 3 November & 8 October \\
\hline $\mathrm{SD}$ & Sunburst & 17 May 2008 & 9.7 & 28 October & 5 November & 3 November & 30 October \\
\hline VA & Alamo & 1 July 2008 & 6.0 & 10 January 2010 & January 2011 & 18 January 2012 & 5 January 2013 \\
\hline IA & Cave-In-Rock & 8 May 2009 & 7.3 & NA & 18 November & 7 November & 4 November \\
\hline
\end{tabular}

$N A$ not applicable since switchgrass was planted in 2009 in IA

\section{Determination of Yield and Subsampling}

Yield was determined by harvesting switchgrass to a height of 10 to $15 \mathrm{~cm}$ with locally available farm-scale equipment at each location. The size of the harvested area in each plot (experimental unit) was about 0.4 ha in IA, NY, OK, and VA and about 0.2 ha in SD. Biomass was baled and weighed. Subsamples (approximately $300 \mathrm{~g}$ ) were collected with a hay probe from the center of bales (OK and SD) immediately after baling or from the windrow (IA, NY, and VA) immediately before baling for chemical analyses. The subsamples were weighed, dried at $60{ }^{\circ} \mathrm{C}$ for $48 \mathrm{~h}$ in a forced-air oven, reweighed to determine dry matter yield, and ground in preparation for chemical analysis. All subsamples were ground in a Wiley mill (Thomas-Wiley Mill Co., Philadelphia, PA) to pass a 1-mm screen and reground to uniformity in a Udycyclone impact mill (Udy Co., Ft. Collins, CO) with a 1-mm screen. Subsamples were not collected at VA and IA in 2009; therefore, quality data are presented from 2010, 2011, and 2012 for VA and IA and from 2009, 2010, 2011, and 2012 for $\mathrm{SD}, \mathrm{NY}$, and $\mathrm{OK}$.

\section{Soil Sampling}

A hydraulic soil probe $(6.6 \mathrm{~cm}$ internal diameter) was used to collect soil samples at initiation of the research in May 2008 for SD, April 2008 for NY, May 2009 for IA, October 2008 for OK, and March 2009 for VA. Three random cores were collected to a depth of $60 \mathrm{~cm}$ from each of the three landscape positions (shoulder, backslope, and footslope) in each plot for a total of nine soil samples plot $^{-1}$. Each core was subdivided into depth increments of 0 to 5,5 to 15,15 to 30 , and 30 to $60 \mathrm{~cm}$, after which soil from each of the nine cores at each depth was composited for analysis. Surface residue was removed before sampling. Soil samples were initially sieved to pass an 8-mm screen and dried in a forced-air oven at $40{ }^{\circ} \mathrm{C}$ until constant mass was attained. Visible plant residue and roots were removed before drying. Dried soil samples were ground to pass a 2-mm screen for chemical analysis.

\section{Chemical Analysis}

Concentrations of total nitrogen (TN), neutral detergent fiber (NDF), acid detergent fiber (ADF), acid detergent lignin (ADL), and ash in switchgrass biomass were predicted for all samples using near infrared reflectance spectroscopy (NIRS) (NIRS Model 5000; Foss NIRSystems, Silver Springs, MD) based on a calibration data set of 216 samples representing 2009, 2010, 2011, and 2012 harvest years [5]. A set of 40 samples was used for crossvalidation. Calibration and validation statistics were generated using WinISI (Version 1.5) system software (Infrasoft International LLC., State College, PA). For calibration and validation samples, NDF and ADF were determined sequentially using an Ankom200 Fiber Analyzer (ANKOM Technology Corp., Fairport, NY), ADL was determined with a Daisy II Incubator (ANKOM Technology Corp., Fairport, NY), and TN was quantified using a Vario Max CNS elemental analyzer (Elementar Instrument, Mt. Laurel, NJ). Hemicellulose was then calculated as the difference between NDF and ADF and cellulose as the difference between ADF and ADL. Ash concentrations were determined using the methods described by Undersander et al. [31].

\section{Statistical Analysis}

Statistical analysis was performed using SAS version 9.2 [28]. PROC GLM was carried out to compare the means of the different treatments. Year, location, and $\mathrm{N}$ rate were considered fixed. The Duncan grouping was used to separate means among year, location, and $\mathrm{N}$ rate treatments when the appropriate $F$ test was significant $(P=0.05)$. Years $1,2,3$, and 4 refer to the first, second, third, and fourth year after establishment, respectively. Year 1 is 2009 for SD, NY, OK, and VA, while 2010 is year 1 for IA. We felt that we could include the IA location in this data set, using number of years after planting as a factor in the model, since establishment had been 
very successful (approximately $70 \%$ stand frequency) at this location in the seeding year.

\section{Results and Discussion}

\section{Precipitation and Temperature}

Growing conditions varied substantially at each location. Average (30-year) annual precipitation ranged from a low of $596 \mathrm{~mm}$ in SD to a high of 1,146 mm in VA (Table 2). Precipitation was highly variable at each location, however. At IA, annual precipitation was $43 \%$ above normal in 2010 and $29 \%$ below normal in 2012, while at OK, annual precipitation never reached the average for that location (ranged from 4 to $39 \%$ below normal). Much of the USA experienced drought conditions in 2012; this was particularly evident at the IA, NY, OK, and VA locations where total annual precipitation in 2012 was $29,12,39$, and $12 \%$ below normal, respectively. While each location experienced below average annual precipitation in 2012, all locations except OK had average or above average precipitation in 2010. Monthly mean temperatures for each location are shown in Table 3. Monthly mean temperatures were generally highest at all locations in 2012 when precipitation was below normal.

\section{Biomass Production}

Year, location, and $\mathrm{N}$ rate significantly affected biomass yield; there was also a location $\times \mathrm{N}$ rate interaction (Table 4). Average biomass yield across locations and $\mathrm{N}$ rates significantly increased from year 1 through year 3 after establishment, while years 3 and 4 were similar in overall yield (Fig. 1). Biomass yield of switchgrass generally increases with year until it is well established and can take up to 3 years to reach its full production potential [24]. Depending on establishment success and region, it may produce one fourth to one third of its yield potential in the establishment year and two thirds or more of its potential the year after planting [1]. However, some reports indicate that with successful establishment, good weed management, good seed quality, and favorable precipitation, switchgrass may produce one half of its yield potential in the establishment year and $75-100 \%$ of its yield potential the year after planting [21]. Schmer et al. [27] noted that for switchgrass grown for bioenergy, a stand establishment threshold of $40 \%$ in the year of seeding is important, while a threshold of $25 \%$ would be adequate for conservation plantings in the Northern Great Plains. Average stand frequencies in the year of establishment for SD and VA were around $30 \%$, while all other locations had stand frequencies that exceeded $50 \%$ (data not shown). Stand frequencies had exceeded $40 \%$ by year 1 at SD and VA as well. Nonetheless, the low initial stand frequency at these two locations likely contributed to the significant increase in yield between years 1 and 2. On the other hand, yields also increased between years 1 and 2 at $\mathrm{OK}$ and $\mathrm{NY}$, both locations with stand frequencies $>50 \%$ in the establishment year.

Although there was a significant location $\times \mathrm{N}$ rate interaction (Table 4), biomass yield was generally highest at NY and lowest at SD (Fig. 2). The order of average biomass yield, from highest to lowest, was $\mathrm{NY}>\mathrm{IA}>\mathrm{VA}>\mathrm{OK}>\mathrm{SD}$. A locally adapted switchgrass cultivar was planted at each location and likely contributed to differences in biomass yield among locations. Alamo (a lowland cultivar utilized in VA) generally shows greater biomass production in the Southern USA compared with Sunburst, Cave-in-Rock, and Blackwell (all upland cultivars utilized in SD, NY and IA, and OK, respectively) in the Northern Great Plains [18]. Fuentes and Taliaferro [4] reported mean switchgrass dry matter yields of lowland cultivars Alamo and Kanlow to be higher than the mean of upland cultivars Cave-In-Rock and Blackwell every year from 1994 through 2000 in Oklahoma. Biomass production of the upland cultivar Cave-In-Rock, which was planted in NY, was generally greater than that of Alamo, which was planted in VA in this study (Fig. 2). However, based on stand frequency, Alamo at the VA location was slower to establish than any of the upland cultivars planted at NY, IA, or OK. The delay in full establishment resulted in decreased yields of this lowland cultivar in year 1 in particular. Tulbure et al. [30] utilized numerous variables to model switchgrass yields across the USA and concluded that genetics or ecotype, among other parameters, was one of the most important factors for explaining switchgrass yield variability.

Initial soil $\mathrm{N}$ concentration could be an important factor affecting production of switchgrass. Stout and Jung [29] reported that switchgrass grown in soil having higher soil $\mathrm{N}$ concentration had higher biomass accumulation. Of all locations, initial soil $\mathrm{N}$ concentration at all soil depths $(0-60 \mathrm{~cm})$ was always highest in NY (Table 5). The order of initial soil N concentration, from highest to lowest, was $\mathrm{NY}>\mathrm{IA}>\mathrm{OK}>$ $\mathrm{SD}>\mathrm{VA}$. However, this order was different from that of overall biomass yield (Fig. 2), and there was no significant correlation between initial soil $\mathrm{N}$ concentration and biomass production (data not shown). The lack of a significant correlation was due at least in part to the fact that yield at VA was higher than that at SD and OK despite having less initial soil N.

Switchgrass responded positively to $\mathrm{N}$ in 6 of 19 location/ year combinations, and there was one location/year combination (NY in year 2) where a significant negative response was noted (Fig. 2). Nitrogen rate had no effect on switchgrass biomass production in year 1 at any location. SD and VA were the two states with a relatively consistent positive relationship between switchgrass yield and $\mathrm{N}$ rate; these are also the two locations with the lowest initial soil $\mathrm{N}$ concentration. In SD, switchgrass yield increased with $56 \mathrm{~kg} \mathrm{~N} \mathrm{ha}^{-1}$ in years 2, 3, 
Table 2 Monthly, total annual, and 30-year average precipitation (mm) at all switchgrass locations from 2010 to 2012 (IA) and 2009 to 2012 (NY, OK, $\mathrm{SD}, \mathrm{VA})$

\begin{tabular}{|c|c|c|c|c|c|c|c|c|c|c|c|c|c|}
\hline Year & January & February & March & April & May & June & July & August & September & October & November & December & Total \\
\hline \multicolumn{14}{|l|}{ IA } \\
\hline 2010 & 28 & 19 & 55 & 93 & 92 & 284 & 173 & 285 & 167 & 12 & 58 & 18 & 1,284 \\
\hline 2011 & 18 & 33 & 20 & 111 & 117 & 128 & 99 & 91 & 51 & 22 & 68 & 57 & 815 \\
\hline 2012 & 7 & 44 & 60 & 122 & 62 & 75 & 37 & 74 & 47 & 59 & 23 & 26 & 637 \\
\hline 30-year avg & 18 & 22 & 53 & 98 & 124 & 124 & 117 & 117 & 80 & 66 & 52 & 29 & 898 \\
\hline \multicolumn{14}{|l|}{ NY } \\
\hline 2009 & 29 & 19 & 77 & 52 & 97 & 120 & 83 & 133 & 63 & 77 & 52 & 46 & 848 \\
\hline 2010 & 67 & 77 & 71 & 58 & 61 & 92 & 82 & 107 & 58 & 178 & 53 & 76 & 980 \\
\hline 2011 & 33 & 94 & 92 & 188 & 157 & 66 & 51 & 118 & 266 & 107 & 57 & 73 & 1,301 \\
\hline 2012 & 58 & 15 & 44 & 81 & 74 & 47 & 40 & 91 & 97 & 106 & 29 & 152 & 834 \\
\hline 30-year avg & 53 & 50 & 67 & 84 & 81 & 101 & 97 & 92 & 94 & 87 & 80 & 61 & 947 \\
\hline \multicolumn{14}{|l|}{$\mathrm{OK}$} \\
\hline 2009 & 43 & 63 & 64 & 121 & 113 & 61 & 45 & 22 & 187 & 248 & 44 & 67 & 1,078 \\
\hline 2010 & 49 & 66 & 62 & 46 & 150 & 101 & 115 & 30 & 150 & 24 & 44 & 10 & 847 \\
\hline 2011 & 8 & 38 & 18 & 220 & 118 & 26 & 7 & 119 & 92 & 48 & 228 & 47 & 969 \\
\hline 2012 & 53 & 55 & 162 & 61 & 36 & 45 & 31 & 50 & 114 & 19 & 26 & 36 & 688 \\
\hline 30-year avg & 49 & 57 & 97 & 97 & 147 & 127 & 64 & 71 & 124 & 115 & 103 & 69 & 1,120 \\
\hline \multicolumn{14}{|l|}{$\mathrm{SD}$} \\
\hline 2009 & 19 & 23 & 34 & 23 & 25 & 79 & 59 & 97 & 129 & 128 & 6 & 1 & 623 \\
\hline 2010 & 26 & 24 & 36 & 33 & 69 & 100 & 64 & 63 & 137 & 83 & 6 & 36 & 677 \\
\hline 2011 & 31 & 20 & 49 & 58 & 100 & 87 & 97 & 32 & 26 & 23 & 2 & 12 & 538 \\
\hline 2012 & 21 & 23 & 14 & 93 & 90 & 43 & 94 & 59 & 1 & 102 & 8 & 35 & 585 \\
\hline 30-year avg & 16 & 14 & 30 & 53 & 77 & 97 & 93 & 74 & 63 & 48 & 19 & 12 & 596 \\
\hline \multicolumn{14}{|l|}{ VA } \\
\hline 2009 & 103 & 35 & 105 & 84 & 166 & 120 & 107 & 184 & 56 & 67 & 234 & 163 & 1,424 \\
\hline 2010 & 189 & 82 & 134 & 44 & 133 & 61 & 87 & 124 & 137 & 89 & 70 & 64 & 1,214 \\
\hline 2011 & 60 & 27 & 106 & 106 & 125 & 50 & 57 & 63 & 173 & 87 & 144 & 76 & 1,074 \\
\hline 2012 & 60 & 26 & 147 & 88 & 85 & 102 & 148 & 50 & 125 & 70 & 11 & 99 & 1,011 \\
\hline 30-year avg & 98 & 81 & 112 & 94 & 103 & 96 & 102 & 85 & 115 & 93 & 83 & 84 & 1,146 \\
\hline
\end{tabular}

and 4. This is similar to the results of Mulkey et al. [23] in SD using switchgrass on CRP lands. With the exception of year 3 in IA, there was no response to $\mathrm{N}$ at OK or IA, while in NY, switchgrass responded negatively to applied $\mathrm{N}$ in year 2 . Based on visual evaluation of switchgrass at the NY location, there appeared to be a problem with lodging, particularly at the higher $\mathrm{N}$ levels. Thus, we suspect that difficulties associated with efficiently harvesting lodged biomass may have contributed to the negative response to $\mathrm{N}$ in year 2 in NY (H. Mayton, personal communication). The two locations (SD and VA) where positive responses to $\mathrm{N}$ occurred also had the lowest initial soil $\mathrm{N}$ concentrations, while switchgrass at the location with the highest initial soil N (NY) either did not respond or responded negatively to $\mathrm{N}$. Although no response to $\mathrm{N}$ occurred at the IA location in years 1 and 2 , there was a response in year 3 . This may indicate that soil $\mathrm{N}$ was insufficient to maintain yields without the addition of fertilizer $\mathrm{N}$ at this location. However, average switchgrass production at $\mathrm{OK}$ increased each year with no response to $\mathrm{N}$ and lower initial soil $\mathrm{N}$ than at IA. On the other hand, switchgrass production in years 1 and 2 at $\mathrm{OK}$ was at least $50 \%$ lower than in years 1 and 2 at IA; thus, less $\mathrm{N}$ would have been removed in biomass.

\section{Chemical Composition}

Year, location, and $\mathrm{N}$ rate significantly affected $\mathrm{N}$ concentration in biomass (Table 4). Averaged across locations and $\mathrm{N}$ rates, the $\mathrm{N}$ concentration in switchgrass biomass the year after establishment (year 1) was about $5 \mathrm{~g} \mathrm{~kg}^{-1}$, which was essentially double that of biomass from harvests in subsequent years (Fig. 3a). The effect of year on $\mathrm{N}$ concentration in switchgrass biomass was especially evident at the $\mathrm{OK}$ and SD locations where biomass production increased significantly from year 1 to year 2, but was less evident at IA and NY 
Table 3 Monthly and 30-year average temperature $\left({ }^{\circ} \mathrm{C}\right)$ at all switchgrass locations from 2010 to 2012 (IA) and 2009 to 2012 (NY, OK, SD, VA)

\begin{tabular}{|c|c|c|c|c|c|c|c|c|c|c|c|c|c|}
\hline Year & January & February & March & April & May & June & July & August & September & October & November & December & Avg \\
\hline \multicolumn{14}{|l|}{ IA } \\
\hline 2010 & -10.0 & -8.9 & 3.3 & 13.3 & 16.7 & 22.2 & 23.9 & 24.4 & 18.9 & 13.3 & 4.4 & -6.7 & 9.6 \\
\hline 2011 & -8.9 & -4.4 & 2.8 & 10.0 & 16.1 & 22.2 & 25.6 & 22.8 & 16.7 & 12.8 & 5.0 & -0.6 & 10.0 \\
\hline 2012 & -1.7 & -1.1 & 11.7 & 12.2 & 19.4 & 22.8 & 26.7 & 22.2 & 17.8 & 10.0 & 5.6 & -2.2 & 11.9 \\
\hline 30-year avg & -6.3 & -3.7 & 3.2 & 10.3 & 16.4 & 21.5 & 23.4 & 22.1 & 18.1 & 11.3 & 3.1 & -4.5 & 9.6 \\
\hline \multicolumn{14}{|l|}{ NY } \\
\hline 2009 & -9.3 & -3.3 & 0.9 & 8.1 & 13.1 & 16.6 & 18.4 & 20.2 & 14.9 & 8.2 & 5.5 & -2.8 & 7.5 \\
\hline 2010 & -5.2 & -4.5 & 2.8 & 9.6 & 15.1 & 19.0 & 21.9 & 20.6 & 16.2 & 9.4 & 3.8 & -4.2 & 8.7 \\
\hline 2011 & -6.6 & -5.4 & -0.5 & 7.7 & 14.7 & 18.9 & 22.2 & 19.7 & 17.2 & 10.1 & 7.2 & 0.7 & 8.8 \\
\hline 2012 & -2.4 & -4.1 & 7.3 & 6.3 & 16.4 & 18.5 & 22.4 & 20.4 & 15.9 & 10.8 & 2.7 & 1.1 & 9.6 \\
\hline 30 -year avg & -4.8 & -3.7 & 0.3 & 7.1 & 13.0 & 18.1 & 20.4 & 19.7 & 15.6 & 9.3 & 4.2 & -1.8 & 8.1 \\
\hline \multicolumn{14}{|l|}{$\mathrm{OK}$} \\
\hline 2009 & -5.4 & 0.7 & 3.9 & 7.3 & 14.3 & 19.6 & 18.4 & 18.3 & 16.4 & 9.1 & 6.7 & -3.1 & 8.9 \\
\hline 2010 & -2.8 & -2.2 & 3.2 & 9.9 & 15.5 & 21.7 & 22.9 & 20.3 & 17.9 & 8.9 & 3.9 & -2.2 & 9.8 \\
\hline 2011 & 0.9 & 3.8 & 11.1 & 17.0 & 19.3 & 27.7 & 31.2 & 29.5 & 20.4 & 16.1 & 10.2 & 5.2 & 16.0 \\
\hline 2012 & 6.1 & 7.3 & 15.5 & 18.0 & 22.2 & 25.9 & 30.0 & 27.5 & 23.3 & 15.1 & 10.4 & 6.2 & 17.3 \\
\hline 30-year avg & 2.3 & 5.3 & 10.2 & 15.4 & 20.4 & 24.7 & 27.8 & 27.1 & 22.8 & 16.7 & 9.5 & 4.2 & 15.5 \\
\hline \multicolumn{14}{|l|}{ SD } \\
\hline 2009 & -14.2 & -8.8 & -2.9 & 5.4 & 13.6 & 17.8 & 19.0 & 18.5 & 16.7 & 3.9 & 3.5 & -11.8 & 5.1 \\
\hline 2010 & -12.2 & -11.2 & 1.2 & 10.3 & 13.3 & 18.9 & 22.1 & 22.6 & 15.7 & 9.8 & 0.7 & -10.5 & 6.7 \\
\hline 2011 & -14.0 & -10.4 & -5.1 & 5.4 & 12.0 & 18.8 & 24.0 & 20.9 & 14.7 & 10.2 & 0.3 & -3.7 & 6.1 \\
\hline 2012 & -5.9 & -4.9 & 6.5 & 8.9 & 15.1 & 20.9 & 24.7 & 20.0 & 15.6 & 6.5 & -0.3 & -7.8 & 8.3 \\
\hline 30-year avg & -11.0 & -8.2 & -1.6 & 6.8 & 13.9 & 19.0 & 22.1 & 20.9 & 15.5 & 7.9 & -1.3 & -8.5 & 6.3 \\
\hline \multicolumn{14}{|l|}{ VA } \\
\hline 2009 & 0.0 & 3.6 & 6.8 & 12.6 & 17.5 & 22.4 & 21.8 & 23.7 & 18.8 & 12.0 & 9.2 & 1.5 & 12.5 \\
\hline 2010 & 0.4 & -0.3 & 7.9 & 14.0 & 18.7 & 24.1 & 24.9 & 24.3 & 20.5 & 14.2 & 6.8 & -0.7 & 12.9 \\
\hline 2011 & 0.3 & 4.1 & 7.4 & 14.0 & 17.5 & 22.8 & 25.3 & 24.0 & 19.6 & 12.4 & 8.7 & 5.0 & 13.4 \\
\hline 2012 & 3.1 & 4.4 & 12.2 & 12.7 & 19.1 & 20.2 & 25.2 & 22.7 & 18.8 & 13.0 & 4.9 & 5.2 & 13.4 \\
\hline 30-year avg & 1.5 & 2.9 & 7.2 & 11.9 & 16.7 & 21.3 & 23.7 & 22.7 & 19.2 & 12.6 & 7.5 & 3.2 & 12.5 \\
\hline
\end{tabular}

where production was similar across years. Production differences between year 1 and year 2 were also high at the VA location, but quality samples were not collected at that location in year 1 so the quality comparison was not possible. Although switchgrass maturity at harvest was not quantified since it was harvested after senescence, greater yields in years subsequent to year 1 at $\mathrm{OK}, \mathrm{SD}$, and VA likely indicate a higher proportion of reproductive tillers which may have contributed to the decline in biomass $\mathrm{N}$ concentration in year 2. Internodes of reproductive tillers contain less $\mathrm{N}$ than the

Table 4 Analysis of variance (ANOVA) and probability values for switchgrass biomass yield and concentrations of nitrogen, cellulose, hemicellulose, lignin, and ash across five locations in the USA

\begin{tabular}{|c|c|c|c|c|c|c|}
\hline & Block & Year $(Y)$ & Location $(L)$ & $\mathrm{N}$ rate (NR) & $Y \times \mathrm{NR}$ & $L \times \mathrm{NR}$ \\
\hline Biomass yield & NS & $<0.001$ & $<0.001$ & $<0.001$ & NS & $<0.001$ \\
\hline Nitrogen & NS & $<0.001$ & $<0.001$ & $<0.001$ & NS & NS \\
\hline Cellulose & NS & $<0.001$ & $<0.001$ & NS & NS & NS \\
\hline Hemicellulose & NS & $<0.001$ & NS & 0.004 & 0.011 & NS \\
\hline Lignin & NS & $<0.001$ & $<0.001$ & NS & NS & NS \\
\hline Ash & NS & $<0.001$ & $<0.001$ & NS & NS & NS \\
\hline
\end{tabular}

$N S$ not significant 
Fig. 1 Average switchgrass biomass production across locations and $\mathrm{N}$ rates for different years. Years 1, 2, 3, and 4 refer to the first, second, third, and fourth year after establishment, respectively. Different letters denote significant differences at 0.05 level of probability

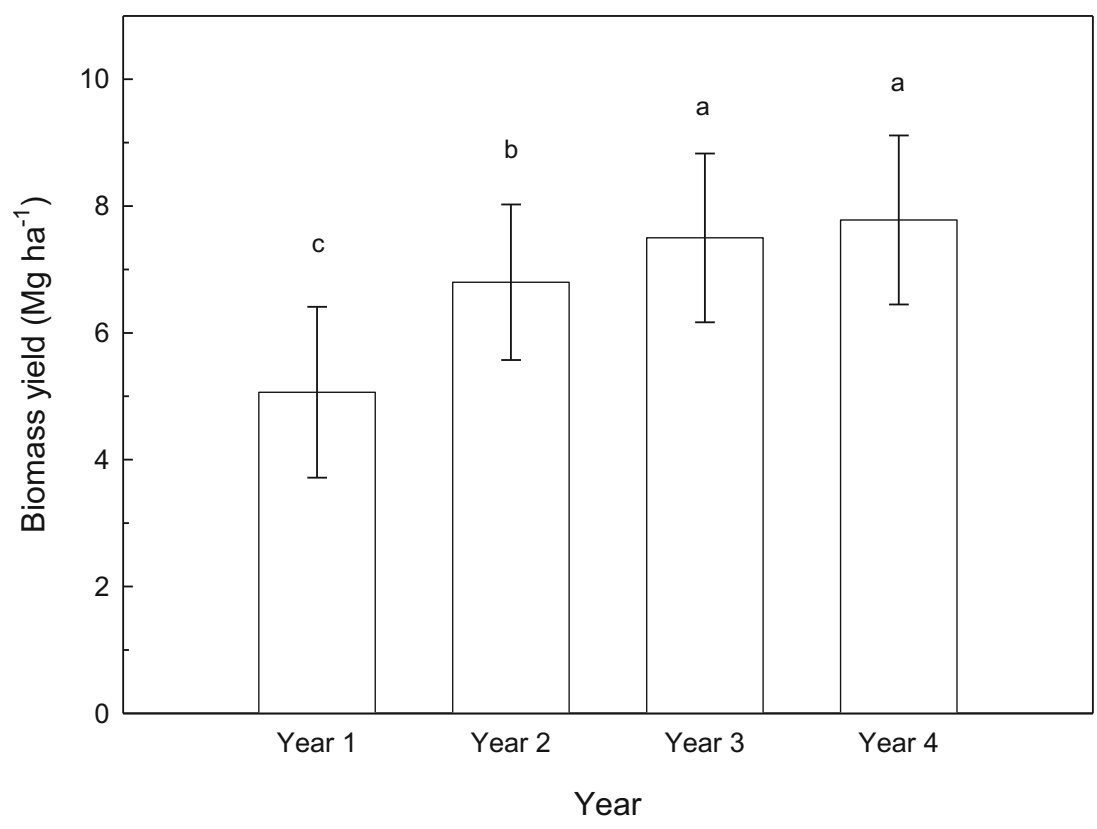

leaves which may have led to decreased $\mathrm{N}$ concentrations in harvested biomass [7].

Switchgrass biomass from the OK location contained a higher concentration of $\mathrm{N}$ than any of the other locations (Fig. 3b). There was significant broadleaf weed encroachment in $\mathrm{OK}$ in year 1 , likely leading to particularly high $\mathrm{N}$ concentration (approximately $8 \mathrm{~g} \mathrm{~N} \mathrm{~kg}^{-1}$ biomass across $\mathrm{N}$ rates) in harvested biomass at this location compared with other locations, and was a primary factor involved in higher average $\mathrm{N}$ concentrations across years. Based on a visual assessment at each location, weeds were a minor or nonexistent component of the harvested biomass in all other years and locations. Biomass from the lowland cultivar Alamo (VA location only) had the lowest overall $\mathrm{N}$ concentration. Cassida et al. [3] found that lowland ecotypes had lower $\mathrm{N}$ concentrations than their upland counterparts when harvested for biomass in the
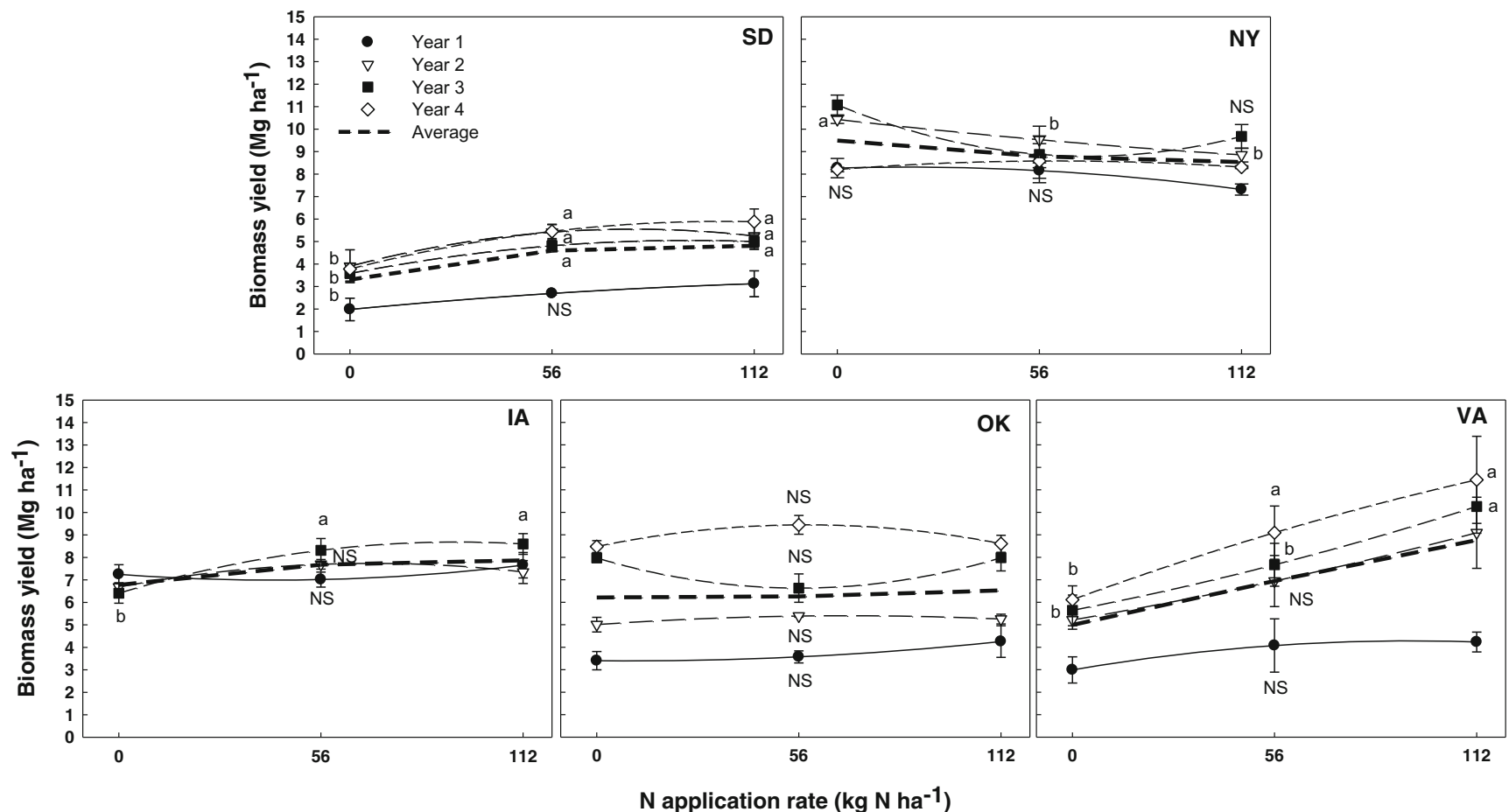

Fig. 2 Biomass yield response to nitrogen at five locations across the USA. Years 1, 2, 3, and 4 refer to the first, second, third, and fourth year after establishment, respectively. Within a given year and location, different letters denote significant differences at 0.05 level of probability. NS indicates not significant at 0.05 level of probability 
Table 5 Initial soil nitrogen concentration at five locations in the USA before switchgrass was planted

Soil depth increment $(\mathrm{cm}) \quad$ Total $\mathrm{N}$ concentration $\left(\mathrm{g} \mathrm{kg}^{-1}\right)$

\begin{tabular}{llllll} 
& SD & NY & IA & OK & VA \\
\hline $0-5$ & $1.93 \mathrm{c}$ & $3.02 \mathrm{a}$ & $2.53 \mathrm{~b}$ & $2.39 \mathrm{~b}$ & $1.12 \mathrm{~d}$ \\
$5-15$ & $1.55 \mathrm{~b}$ & $2.29 \mathrm{a}$ & $2.26 \mathrm{a}$ & $1.68 \mathrm{~b}$ & $0.55 \mathrm{c}$ \\
$15-30$ & $1.04 \mathrm{~b}$ & $1.80 \mathrm{a}$ & $1.86 \mathrm{a}$ & $1.17 \mathrm{~b}$ & $0.42 \mathrm{c}$ \\
$30-60$ & $0.50 \mathrm{c}$ & $1.22 \mathrm{a}$ & $1.03 \mathrm{ab}$ & $0.86 \mathrm{~b}$ & $0.29 \mathrm{c}$
\end{tabular}

Values with the same letter within a row are not significantly different at a probability level of 0.05

South Central USA. In addition, harvest of Alamo at VA did not occur until mid-January, while other locations were harvested during October-December; thus, increased leaf loss may have occurred and caused even further reductions in $\mathrm{N}$.

Averaged across locations and years, switchgrass $\mathrm{N}$ concentration was about $34 \%$ greater at the highest $\mathrm{N}$ level $\left(112 \mathrm{~kg} \mathrm{~N} \mathrm{ha}^{-1}\right.$ ) compared with 0 or $56 \mathrm{~kg} \mathrm{~N} \mathrm{ha}^{-1}$ (Fig. 3c), but there was no difference between the $0 \mathrm{~N}$ control and the $56-\mathrm{kg} \mathrm{N} \mathrm{ha}{ }^{-1}$ rates. These results are similar to those of Kering et al. [12] who found that biomass $\mathrm{N}$ concentration was higher with the application of $\mathrm{N}$ and $\mathrm{K}$ compared with the no-fertilizer control in the central USA. The magnitude of the effect of $\mathrm{N}$ was less than that of either location or year, however.

Perennial C4 grasses, such as switchgrass, translocate up to $30 \%$ of shoot $\mathrm{N}$ to rhizomes and roots during senescence [9]. Parrish and Wolf [24] observed a significant redistribution of $\mathrm{N}$ into belowground biomass of switchgrass at the end of the growing season. Heggenstaller et al. [10] also observed that $\mathrm{N}$ rate affected switchgrass root biomass and nutrient partitioning, with $140 \mathrm{~kg} \mathrm{~N} \mathrm{ha}^{-1}$ maximizing root biomass. Switchgrass in years 2, 3, and 4 may not have required as much applied $\mathrm{N}$ as in year 1 because some of the $\mathrm{N}$ from the first year was retained in belowground biomass. This might partially account for lower $\mathrm{N}$ concentration in biomass grown in years 2, 3, and 4 compared with year 1 as well.

Year and location significantly affected switchgrass cellulose concentration, but $\mathrm{N}$ rate did not. Year and $\mathrm{N}$ rate affected hemicellulose concentration in biomass, and there was also an interaction effect for year $\times \mathrm{N}$ rate. Of all the quality parameters measured, hemicellulose was the only one not affected by location (Table 4). Averaged over locations and $\mathrm{N}$ rates, cellulose and hemicellulose concentrations in biomass varied substantially over time (Figs. 4a and 5a) and are due at least in part to changes in environmental conditions from year to year. Both cellulose and hemicellulose concentrations increased from year 1 to year 2 and are probably related to the production of larger, reproductive tillers in year 2 after full establishment of switchgrass at all locations. The year-to-year variability in both cellulose and hemicellulose was similar to the results seen by Mulkey et al. [23] for switchgrass harvested
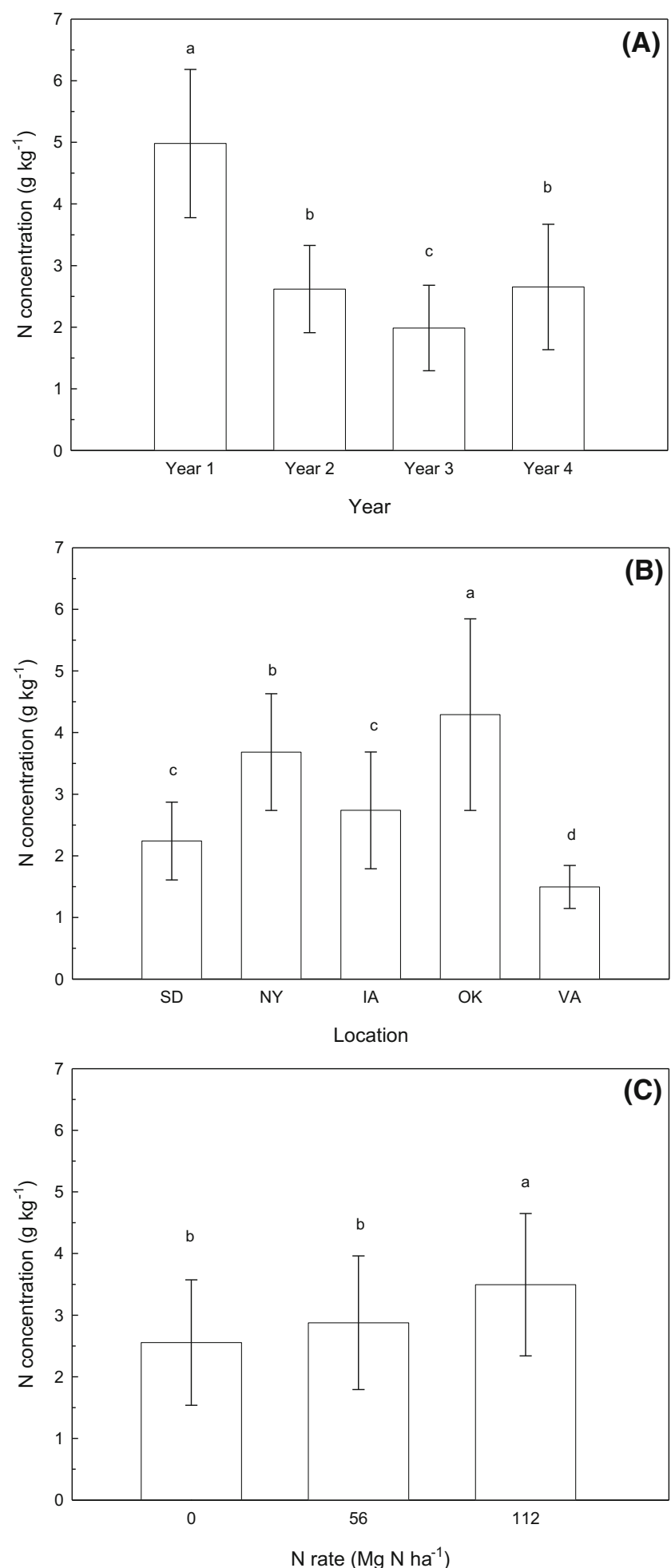

Fig. 3 Average $\mathrm{N}$ concentration in biomass across locations and $\mathrm{N}$ rates for different years (a), across years and $\mathrm{N}$ rates at different locations (b), and across years and locations at different $\mathrm{N}$ rates (c). Years 1, 2, 3, and 4 refer to the first, second, third, and fourth year after establishment, respectively. Different letters denote significant differences at 0.05 level of probability

across three growing seasons and three locations in South Dakota, USA, but slightly different from the results of Lemus 

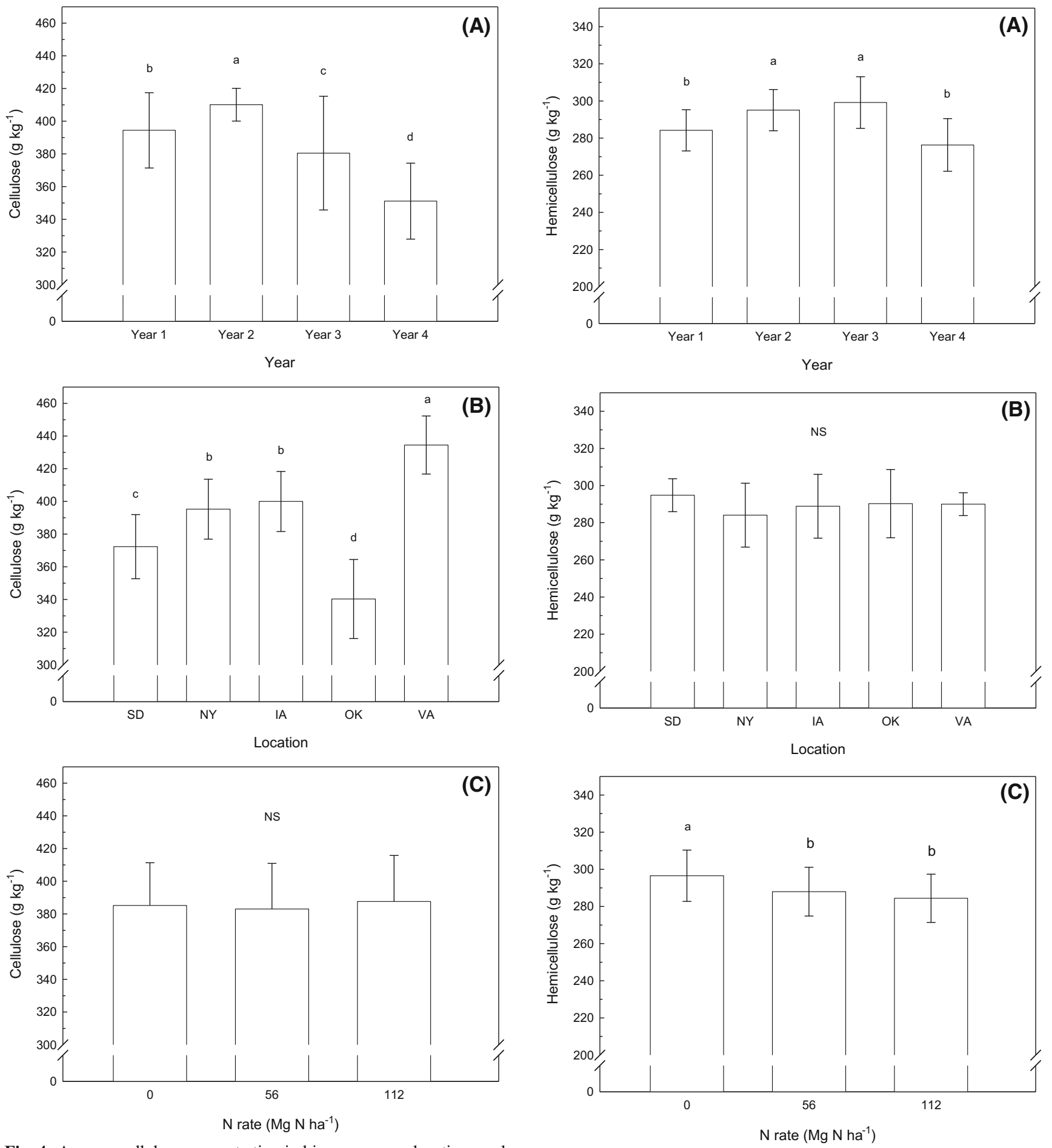

Fig. 4 Average cellulose concentration in biomass across locations and $\mathrm{N}$ rates for different years (a), across years and $\mathrm{N}$ rates at different locations (b), and across years and locations at different $\mathrm{N}$ rates (c). Years $1,2,3$, and 4 refer to the first, second, third, and fourth year after establishment, respectively. Different letters denote significant differences at 0.05 level of probability. NS indicates not significant at 0.05 level of probability

et al. [14] who reported a linear trend of increasing cellulose and hemicellulose concentrations in switchgrass across years as yields increased.

Fig. 5 Average hemicellulose concentration in biomass across locations and $\mathrm{N}$ rates for different years (a), across years and $\mathrm{N}$ rates at different locations (b), and across years and locations at different $\mathrm{N}$ rates $(\mathbf{c})$. Years $1,2,3$, and 4 refer to the first, second, third, and fourth year after establishment, respectively. Different letters denote significant differences at 0.05 level of probability

Cellulose concentrations varied significantly among locations, but there was no effect of location on hemicellulose (Figs. $4 \mathrm{~b}$ and $5 \mathrm{~b}$ ). Averaged across years and $\mathrm{N}$ rates, 

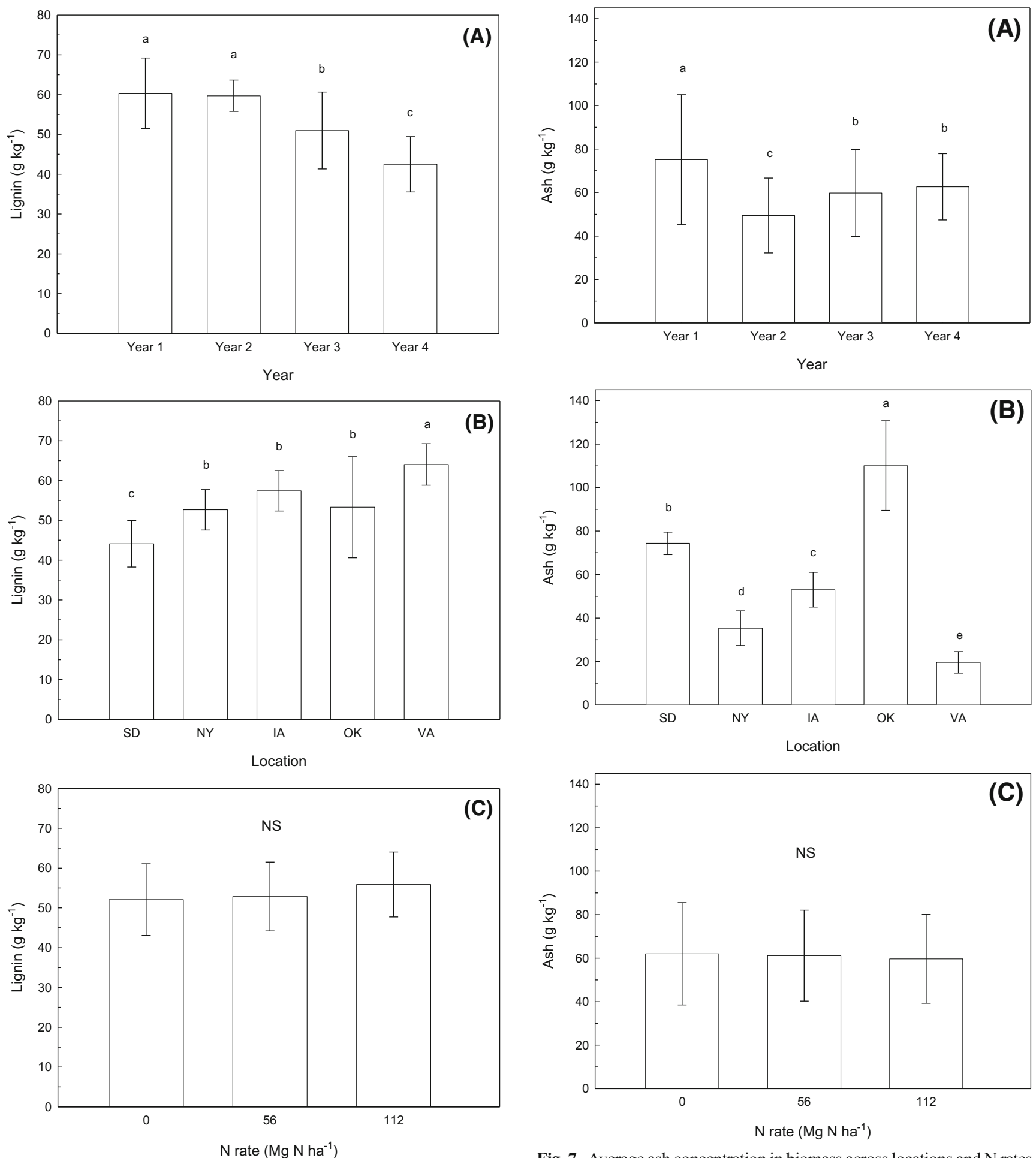

Fig. 6 Average lignin concentration in biomass across locations and $\mathrm{N}$ rates for different years (a), across years and $\mathrm{N}$ rates at different locations (b), and across years and locations at different $\mathrm{N}$ rates (c). Years 1, 2, 3, and 4 refer to the first, second, third, and fourth year after establishment, respectively. Different letters denote significant differences at 0.05 level of probability. NS indicates not significant at 0.05 level of probability

switchgrass at $\mathrm{OK}$ had the lowest cellulose concentration and VA the highest with the other locations intermediate to these

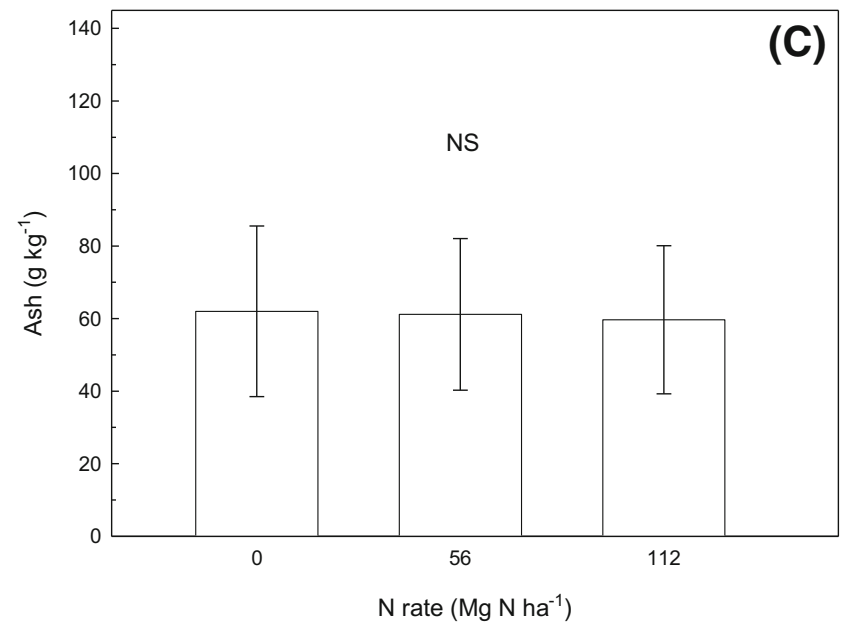

Fig. 7 Average ash concentration in biomass across locations and $\mathrm{N}$ rates for different years (a), across years and $\mathrm{N}$ rates at different locations (b), and across years and locations at different $\mathrm{N}$ rates (c). Years 1, 2, 3, and 4 refer to the first, second, third, and fourth year after establishment, respectively. Different letters denote significant differences at 0.05 level of probability. NS indicates not significant at 0.05 level of probability

two. The higher cellulose concentration in biomass grown in VA was not surprising since Alamo, a lowland cultivar, was planted at this location. This was similar to the results of 
Lemus et al. [15] who reported higher cellulose and hemicellulose concentrations in Alamo compared with the upland cultivars Blackwell and Cave-In-Rock in Iowa. The difference in cellulose concentrations between the upland and lowland cultivars may also impact biomass conversion processes and product yield.

There was a year $\times \mathrm{N}$ rate interaction for switchgrass hemicellulose concentration (Table 4). In 3 of 4 years, hemicellulose concentration decreased with increasing $\mathrm{N}$, and in 1 year (year 1), the concentration of hemicellulose remained relatively constant across $\mathrm{N}$ rates (data not shown). Thus, the general trend was for hemicellulose to decrease with increasing $\mathrm{N}$ rate (Fig. 5c), similar to what Leymus et al. [14] noted in a previous work in IA.

Year and location significantly affected lignin and ash concentrations in biomass, but $\mathrm{N}$ rate did not nor were there any interaction effects (Table 4). Both lignin and ash generally decreased with age of the stand (Figs. 6a and 7a) which is comparable to the results reported by Leymus et al. [14] for these chemical constituents. Averaged across years and $\mathrm{N}$ rates, lignin was the highest and ash the lowest with Alamo switchgrass grown at the VA location, while Sunburst switchgrass at the SD location had the lowest average lignin concentration (Figs. 6b and $7 b)$. Lignin and ash were both highest in year 1 in OK (data not shown) when broadleaf weeds were problematic during establishment. Ash was particularly high at $\mathrm{OK}$ in year $1\left(>160 \mathrm{~g} \mathrm{~kg}^{-1}\right.$ and two to four times the ash concentration in switchgrass from other locations) and resulted in OK having the highest overall ash concentration among all locations (Fig. 7b).

\section{Conclusion}

Nitrogen application rate had a positive effect on switchgrass biomass production at the field scale at three of five locations in trials conducted across the USA over a 4-year period. Nitrogen was particularly important for switchgrass production on fields with low initial soil $\mathrm{N}$ tests (SD and VA). Yields were lowest in year 1 (the first year after planting) at all locations and increased substantially in year 2, particularly at sites with lower stand frequencies in the establishment year. Nitrogen application rate was less important in terms of switchgrass compositional characteristics than location or year of harvest which may be particularly important to conversion facilities desiring a relatively consistent product.

Acknowledgments This research was supported by funding from the North Central Regional Sun Grant Center at South Dakota State University through a grant provided by the US Department of Energy Bioenergy Technologies Office under award number DE-FC36-05GO85041.
Open Access This article is distributed under the terms of the Creative Commons Attribution License which permits any use, distribution, and reproduction in any medium, provided the original author(s) and the source are credited.

\section{References}

1. Bransby DI (2005) Switchgrass profile. Bioenergy Feedstock Information Network (BFIN), Oak Ridge National Laboratory. http://bioenergy.ornl.gov/papers /misc/switchgrass-profile.html. Retrieved 2008-05-24.

2. Casler MD, Boe AR (2003) Cultivar $\times$ environment interactions in switchgrass. Crop Sci 43:2226-2233

3. Cassida KA, Muir JP, Hussey MA, Read JC, Venuto BC, Ocumpaugh WR (2005) Biofuel component concentrations and yields of switchgrass in South Central US environments. Crop Sci 45:682-692

4. Fuentes RG, Taliaferro CM (2002) Biomass yield stability of switchgrass cultivars. In: Janick J, Whipkey A (eds) Trends in new crops and new uses. ASHS Press, Alexandria, VA, pp 276-282

5. Garcia-Ciudad A, Garcia-Criado B, Perez-Corona ME, Vazquez de Aldana BR, Ruano-Ramos AM (1993) Application of near-infrared reflectance spectroscopy to chemical analysis of heterogeneous and botanically complex grassland samples. J Sci Food Agric 63:419-426

6. Garten CT, Wullschleger SD (2000) Soil carbon dynamics beneath switchgrass as indicated by stable isotope analysis. J Environ Qual 29:645-653

7. Griffin JL, Jung GA (1983) Leaf and stem forage quality of big bluestem and switchgrass. Agron J 75:723-726

8. Hall KE, George JR, Riedl RR (1982) Herbage dry matter yields of switchgrass, big bluestem, and indiangrass with $\mathrm{N}$ fertilization. Agron J 74:47-51

9. Heckathorn SA, Delucia H (1996) Retranslocation of shoot nitrogen to rhizomes and roots in prairie grasses may limit loss of $\mathrm{N}$ to grazing and fire during drought. Funct Ecol 10(3):396-400

10. Heggenstaller AH, Moore KJ, Liebman M, Anex RP (2009) Nitrogen influences biomass and nutrient partitioning by perennial, warmseason grasses. Agron J 101(6):1363-1371

11. Jung GA, Shaffer JA, Stout WL (1988) Switchgrass and big bluestem responses to amendments on strongly acid soil. Agron J 80:669-676

12. Kering MK, Butler TJ, Biermacher JT, Mosali J, Guretzky JA (2013) Effect of potassium and nitrogen fertilizer on switchgrass productivity and nutrient removal rates under two harvest systems on a low potassium soil. Bioenerg Res 6:329-335

13. Lee DK, Owens VN, Doolittle JJ (2007) Switchgrass and soil carbon sequestration response to ammonium nitrate, manure, and harvest frequency on conservation reserve program land. Agron J 99:462468

14. Lemus R, Brummer EC, Burras CL, Moore KJ, Barker MF, Molstad NE (2008) Effects of nitrogen fertilization on biomass yield and quality in large fields of established switchgrass in southern Iowa, USA. Biomass Bioenergy 32:1187-1194

15. Lemus R, Brummer EC, Moore KJ, Molstad NE, Burras CL, Barker MF (2002) Biomass yield and quality of 20 switchgrass populations in southern Iowa, USA. Biomass Bioenergy 23:433-442

16. Liebig MA, Kronberg SL, Gross JR (2008) Effects of normal and altered cattle urine on short-term greenhouse gas flux from mixedgrass prairie in the Northern Great Plains. Agr Ecosyst Environ 125(1-4):57-64

17. McLaughlin SB, DeLaTorreUgarte DG, Garten CT, Lynd LR, Sanderson MA, Tolbert VR, Wolf DD (2002) High-value renewable energy from prairie grasses. Environ Sci Technol 36:2122-2129 
18. McLaughlin SB, Kszos LA (2005) Development of switchgrass (Panicum virgatum) as a bioenergy feedstock in the United States. Biomass Bioenerg 28(6):515-535

19. McLaughlin SB, Samson R, Bransby D, Wiselogel A (1996) Evaluating physical, chemical, and energetic properties of perennial grasses as biofuels. In: Abstracts of BioEnergy '96-The Seventh National Bioenergy Conference: partnerships to develop and apply biomass technologies, Nashville, TN. September 15-20

20. McLaughlin SB, Walsh ME (1998) Evaluating environmental consequences of producing herbaceous crops for bioenergy. Biomass Bioenergy 14:317-324

21. Mitchell RB, Vogel KP, Schmer MR (2012) Switchgrass (Panicum virgatum) for biofuel production. Sustainable Ag Energy Community of Practice, eXtension (revised). (http://extension.org/pages/ Switchgrass_for_Biofuel_Production)

22. Muir JP, Sanderson MĀ, Ocumpaugh WR, Jones RM, Reed RL (2001) Biomass production of 'Alamo' switchgrass in response to nitrogen, phosphorus, and row spacing. Agron J 93:896-901

23. Mulkey VR, Owens VN, Lee DK (2006) Management of switchgrass-dominated conservation reserve program lands for biomass production in South Dakota. Crop Sci 46:712-720

24. Parrish DJ, Wolf DD (1992) Managing switchgrass for sustainable biomass production. In: Proc. Symp. liquid fuels from renewable resources, Nashville, TN, 13-14 December 1992. ASAE: p. 34-39

25. Sanderson MA, Read JC, Reed RL (1999) Harvest management of switchgrass for biomass feedstock and forage production. Agron J 91:5-10
26. Schmer MR, Liebig MA, Vogel KP, Mitchell R (2011) Field-scale soil property changes under switchgrass managed for bioenergy. Global Change Biol Bioenergy 3:439-448

27. Schmer MR, Vogel KP, Mitchell RB, Moser LB, Eskridge KM, Perrin RK (2005) Establishment stand thresholds for switchgrass grown as a bioenergy crop. Crop Sci 46:157-161

28. SAS Institute Inc (2008) SAS/STAT ${ }^{\circledR} 9.2$ user's guide. SAS Institute Inc, Cary, NC

29. Stout WL, Jung GA (1995) Biomass and nitrogen accumulation in switchgrass: effects of soil and environment. Agron J 87(4): 663-669

30. Tulbure MG, Wimberly MC, Boe A, Owens VN (2012) Climatic and genetic controls of yields of switchgrass, a model bioenergy species. Ag Ecosyst Eviron 146(1):121-129

31. Undersander D, Mertens DD, Thiex N (1993) Total ash in forages. Forage analysis procedures. National Forage Testing Association, Omaha

32. Vogel KP, Brejda JJ, Walters DT, Buxton DR (2002) Switchgrass biomass production in the Midwest USA: harvest and nitrogen management. Agron J 94:413-420

33. Vogel KP, Masters RA (2001) Frequency grid - a simple tool for measuring grassland establishment. J Range Manage 54:653655

34. Wullschleger SD, Davis EB, Borsuk ME, Gunderson CA, Lynd LR (2010) Biomass production in switchgrass across the United States: database description and determinants of yield. Agron J 102:11581168 